\title{
Mapa Teatro, Mockus, and Modos de hacer
}

\section{Geoffrey Wilson}

Bogotá's barrio Santa Inés, known colloquially as El Cartucho, was paradoxically at once one of the most dangerous neighborhoods in the capital and a refuge for many of the city's impoverished citizens, many of whom were among Colombia's more than six million internally displaced persons ${ }^{1}$ - those who have fled from the violence of the ongoing guerrilla warfare more prevalent in the country's rural regions. At the dawn of the twenty-first century, Bogotá had become known for its history of murders, kidnappings, and bombings, and while foreign governments labeled the city a perilous place to visit, the local residents had become afraid of El Cartucho. This four-hundred meter by four-hundred meter community was located a couple blocks from Bogotá's center of power, the Plaza de Bolívar. On the four sides of the plaza sit Colombia's Palacio de Justicia, the Catedral Primada de Colombia, Colombia's Capitolio Nacional, the Liévano Palace (seat of Bogotás mayor), and the Colegio Mayor de San Bartolomé, Colombia's oldest educational institution founded in 1604. If the Plaza de Bolívar is Bogotá's center of executive, legislative, judicial, religious, and educational power, El Cartucho, as Rolf Abderhalden, who serves as Mapa Teatro's Co-Artistic Director, has written, "era un sitio específico del miedo - el centro de temor - de la ciudad" (92). El Cartucho was known to be a home to drug dealers, addicts, and prostitutes, but it was also a haven for a variety of other informal economies, particularly recycling. Despite being one of Bogotá's oldest neighborhoods with a rich cultural history, El Cartucho-its buildings, its streets, and its histories of human lives - has been erased from the face of the Earth by the wrecking ball of gentrification and the bulldozer of neoliberalism. This small neighborhood, which had been the site of homes, businesses, and the daily traffic of around twelve-thou- 
sand lives, was demolished to make room for the open and verdant Parque Tercer Milenio.

On 22 September 2012, Rolf Abderhalden and Antanas Mockus, former two-time mayor of Bogotá ${ }^{2}$, appeared together on stage behind a translucent projection screen in Witness to the Ruins at a gathering titled "Truth is Concrete," which its organizers describe as "A 24/7 marathon camp on artistic strategies in politics and political strategies in art" (Truth is Concrete). Witness to the Ruins is a multimedia documentary that combines video projection and live performance. The touring performance, which in its Spanish iterations is known as Testigo a las ruinas, documents the demolition of El Cartucho, as well as a series of performance installations created by Mapa Teatro with the residents of El Cartucho. These performance installations recounted the personal histories of some of the residents through recorded interviews and staged some of their daily rituals through live performance on the rubble of the barrio itself. While Testigo a las ruinas had been produced numerous times internationally, this particular version was notable for the presence of Mockus. It was Mockus's second mayoral administration that enlisted Mapa Teatro to develop a memorial artwork on El Cartucho, originally conceived as a physical memorial, and provided the initial funding. Mockus inherited the demolition of El Cartucho from the previous mayor, Enrique Peñalosa (1998-2000). Mockus and Mapa Teatro have more in common, however, than the collaboration on El Cartucho and a shared presence on stage; they have both created performances that have challenged the cultural citizenship of Bogotá, that have attempted interventions into what it means to be a citizen of the city, confronting notions of who belongs to the cultural sphere of the city and what is expected of those who belong. As mayor, Mockus implemented a series of sixteen projects known as Cultura ciudadana over the course of his two mayoral administrations, each of which was designed to alter public moral behavior, either by modeling new alternative behaviors, as when he dressed as "Super Mockus" and went about the city picking up trash, or by symbolically eliminating old behaviors, as when he "vaccinated" hundreds of schoolchildren against violence with symbolic vaccines in a public performance. Mockus's public theatrical performances, many of which included costumes and props, arose out of the belief that the high rate of violent crimes in Bogotá in the 1980s and 90 s were not just the product of drug cartels, but also a breakdown in the three systems that regulate public interactions: the law, morality, and culture. Mockus's political performances intervene in the cultural citizenship 
of Bogotá by directly attempting to realign the expected moral comportment of the citizens.

Perhaps the most famous of Mockus's programs involved what have come to be known as his traffic mimes. In 1997, he hired 20 mimes and directed them to publicly shame drivers who ignored basic traffic laws, and to applaud acts of kindness and goodwill, deliberately reinscribing a system of moral mutual interaction within the community. This program was so successful that the number of mimes was raised to 200 the next year. In another of the Cultura ciudadana programs, Mockus mailed thousands of large laminated flash cards to the citizens of Bogotá. On one side was a green thumbs up, and on the other a red thumbs down. The citizens were encouraged to use these cards as a simple system by which to judge the behavior of their fellow citizens, modeling a new pattern of public moral behavior to combat the disillusionment legible in the city's residents after more than half a century of violent conflict. The success of Mockus's Cultura ciudadana was palpable; according to María Victoria Llorente and Ángela Rivas, the homicide rate in the city fell from its peak of 80 per 100,000 inhabitants in 1993 to 22 homicides per 100,000 in 2004 (5). While Cultura ciudadana can by no means claim sole responsibility for the significant drop in violent crimes, it was certainly a contributing factor. The central proposition of Cultura ciudadana, that it is possible to directly intervene into the patterns of public moral behavior of a community by modeling positive alternative behaviors, echoes a recurring focus on the lives of ordinary citizens in the artistic practice of Mapa Teatro.

The public performances of both Mockus and Mapa Teatro constitute what I call citizenship performances. These projects directly confront prevailing notions of who belongs to the cultural community of Bogotá and/ or how individuals within the community relate to each other. The political strategies of Mockus's administration and the aesthetic performances and installations of Mapa Teatro reveal the inextricable relationship between communities and the spaces they share. Moreover, these embodied performances articulate a fundamentally heterogeneous spatial imaginary, one in which communities are formed based on shared social space and reciprocally negotiable systems of meaning making. The prevalence of everyday tasks and rituals of the citizens of El Cartucho in the performance installations developed by Mapa Teatro with the barrio's residents reveals how the artists imagine social space. Abderhalden has written that by demolishing El Cartucho, “...se ha puesto fin a una parte de nuestra historia, de nuestra historia 
social y urbana que es, en definitiva, una historia de modos de hacer, de prácticas sociales inéditas, de historias de vida irreemplazables, de inigualables historias de sobrevivencia" (92-93). Abderhalden touches on the notion that spaces are haunted by more than just the events and people that have visited them. They are haunted, too, by the patterns of behavior uniquely situated in each place, the modos de hacer, as Abderhalden calls them, that evolve over time and within a specific social space, which he refers to as a singularity: "El fin de la historia de una singularidad local que deviene, al desaparecer, un no-lugar, homogéneo y global" (93). The homogeneous and globalized non-place echoes French anthropologist Marc Augé, for whom non-places are those transitory sites that lack unique social history. Train stations, shopping malls, and hotels are examples of these non-places - locations that are duplicated around the globe, buildings that carry no locally-unique social history. The Parque Tercer Milenio, once one of Bogotás oldest historic neighborhoods, has become one such non-place whose history of human behaviors, of modos de hacer, has been wiped clean.

Mapa Teatro's works on the barrio El Cartucho, documented by Testigo a las ruinas, began as a memorial about the space, about the loss of one of the city's oldest neighborhoods, but became a testimony to/for/by those who had lived there. As a self-described "laboratorio de la imaginación social," their engagement with the citizens of this stigmatized neighborhood began with a year-long workshop in which fifteen current and recently evicted residents participated. Working with the artists of Mapa Teatro, these residents created two performances, staged exactly one year apart on 15 December 2002 and again on 15 December 2003. These performances, titled Prometeo: Primer Acto and Prometeo: Acto Segundo, and sometimes referred to jointly as Proyecto Prometeo, re-created the living spaces of these residents using their own furniture, re-placing them on the rubble of the neighborhood after its demolition. Following Proyecto Prometeo, an interactive art installation was built in Mapa Teatro's headquarters on Carrera Séptima, about fourteen blocks north of El Cartucho. Re-corridos (2003) incorporated video and audio documentation of the demolition of El Cartucho, as well as debris from the neighborhood (including the front doorway of the last building to be demolished, through which visitors passed to enter the exhibition) and bits of recorded interviews collected from the residents. The third performance installation of the series, La limpieza de los establos de Augias (2004), was a video installation in two parts. As the construction was underway to transform El Cartucho into the Parque Tercer Milenio, cameras 
provided a live-feed of the construction, broadcast by video projectors on the walls of Museo de Arte Moderno de Bogotá, or MAMBO. At the same time video monitors had been installed along the construction fence built around the site of El Cartucho and played looped video footage of the neighborhood as it had been before and during its deconstruction, making visible to passersby the history of the site, even while the present ongoing construction was obscured by the fencing. In order to experience the installation as a whole, visitors to MAMBO had to travel to the construction site, and visitors to the construction site had to travel to MAMBO. The final iteration of Mapa Teatro's work with El Cartucho is Testigo a las ruinas, which has been performed worldwide since 2005. Juana Ramírez, the last person to have lived in El Cartucho, frequently appears in the performance, setting up a make-shift cart in front of the projection screens and making arepas and chocolate (two quintessentially Colombian foods) during the performance.

Mockus and Mapa Teatro have approached cultural citizenship from different, but complimentary perspectives: Mockus as politician engaging in performance, and Mapa Teatro as performing artists engaging with the politics of social space. The strategies of the artists and politician differ in more than discipline: Mapa Teatro's work with El Cartucho seeks to establish the cultural citizenship of a marginalized population, while Mockus's Cultura ciudadana seeks to alter the public moral comportment of the citizenry. Both, then, seek to improve the cultural citizenship of Bogotá through public performance. This article thinks through the ways in which Mapa Teatro and Mockus have approached social space, working to unveil the relationship between Mapa Teatro's artistic practice and Mockus's cultural politics in order to shed new light on what geo-ethnographer Karen Till has called their "alternative spatial imaginaries" — building on her analysis by exploring how repertoires of performance are shaped by social space and vice versa, and how artists and politicians have used performance to intervene into these histories.

If cultural citizenship and political citizenship are, as Isin and Wood suggest, relational and mutually constitutive, it follows that the granting of legal rights (and human rights) is directly related to which groups of people are perceived to be fully belonging to a cultural community or nation-state. That is to say, groups on the margins of society, those that are perceived as non-members of society, those who are perceived to contribute less than a full share, those that speak other languages, or have different histories, different religions, different clothes, different skin, are frequently denied the 
human and legal rights granted to those who meet normative perceptions of citizenship. Thus, the expansion of perceived cultural boundaries to include new communities helps guarantee the rights and responsibilities of those communities. If legal citizenship is constructed from perceived cultural citizenship, then performances that challenge and realign the boundaries of cultural citizenship also challenge injustices in political and social formations of citizenship. It follows then that there are two avenues by which the cultural and political citizenship of a community might be challenged. First, new groups of people may be incorporated (using this term mindfully-literally embodied, made a part of the body politic...) into a cultural community by making their bodies visible, by acknowledging their voices and histories, as in the series of performances and installations created by Mapa Teatro on El Cartucho. Second, the rights and responsibilities of citizens may be augmented, altered, or destabilized, as was the intent behind Mockus's Cultura ciudadana. These two projects enable us to consider how performances in public social spaces open opportunities to engage with their audiences as citizens, as political bodies-in-space, extending the experience of the performance beyond an act of reception to a constitutive experience of communal identity reformation. Performances in public social spaces might ask: "Who are we?" or "How do we behave collectively?" They demand that spectators reencounter social space in new ways, renegotiating how those spaces are formed, socially, and in turn, refocusing how social spaces construct community and citizenship.

The historical discourse on cultural citizenship has somewhat obscured the social space in which, and with which, citizenship is constructed. This logic derives from a discourse that has predominantly linked citizenship to a nation or state, ${ }^{3}$ and it follows that since the spatial boundaries of legal citizenship are defined by formal state boundaries already present on the map, the relationship between citizenship and public space is occasionally overlooked or underplayed. While Mockus's cultural politics challenge the expected behavior (the rights and responsibilities) of the citizens of Bogotá by modeling or enabling positive alternative moral behaviors on the streets of the city, Mapa Teatro's work with El Cartucho re-centers the community by re-placing fragments of their lives and homes on the rubble of the former barrio, thereby reasserting the cultural membership of a stigmatized community. Thus, both Mockus and Mapa Teatro engaged cultural citizenship spatially, broadening membership and realigning the rights and responsibilities of those who belong. They demonstrate that performances in social 
space can resituate cultural citizenship and alter what it means to belong to a community, who belongs to the community, and how individuals in the community behave collectively.

This article investigates the series of performance installations Mapa Teatro created with the residents of El Cartucho and documented in the culminating Testigo a las ruinas, deploying a cultural materialist methodology, following Jen Harvie's Theatre \& the City. Furthermore, I consider the relationship Mapa Teatro has with Antanas Mockus, as he is both the politician behind Mapa Teatro's original funding for the project, as well as an eventual participant, to illuminate how citizenship performances of both artists and politicians have functioned in Bogotá. I develop a theoretical approach to investigate how the artists and politician share an understanding of citizenship/belonging that emphasizes the repertoires of behavior embedded within social space. My focus on these behavioral histories builds on the valuable work of those who have written on Mapa Teatro, particularly Till, who adroitly confronts the dissonance between neoliberal imaginaries of urban social space, in which parcels of land are viewed as property, and the messy results of gentrifying improvements, particularly on the poor, whose homes are erased and whose lives are displaced, and Ileana Diéguez, who investigates how Mapa Teatro's work reconstructs the collective memory of Bogotá. Additionally, I follow Doreen Massey's work to resituate social space as lived, relational, and heterogeneous, and engage with Vicky Unruh's work linking ruins with critical reflection on otherness and change.

\section{Mapa Teatro and El Cartucho}

Once a slum characterized by drug dens, dealers, addicts, and prostitutes, and reeling from the stench of mounds of refuse, this stigmatized neighborhood was bulldozed by Enrique Peñalosa's mayoral administration in the name of gentrification. Peñalosa made his name by improving the infrastructure of Bogotá and "greening" up the city's blighted sites. El Cartucho was replaced by a large park with numerous playgrounds, public amphitheaters, walking paths, and open grass fields. The Parque Tercer Milenio was completed in 2003. Residents of the neighborhood were given some relocation assistance by the city, but this assistance largely ignored the fact that the residents' livelihoods were destroyed just as their homes were. The streets of El Cartucho had been home to an informal recycling economy, bolstered by the neighborhood's proximity to the central bus terminal for the city's mass transit system, TransMilenio, another of Peñalosa's projects. 
The removal of the residents of El Cartucho from the center of the city, then, also made access to the city's transportation network more difficult, and those whose livelihoods depended on the recycling economy were now forced to adapt.

Working with the artists of Mapa Teatro over the course of a year, the residents of El Cartucho developed Proyecto Prometeo in response to Heiner Müller's short text on the Prometheus myth. ${ }^{4}$ In Müller's version of the story, the titan Prometheus is caught giving fire to humans. As punishment, Prometheus is chained to a cliff in the Caucasus Mountains, his liver regenerating every day after being eaten by a dog-headed eagle. Prometheus survives for three thousand years by consuming the eagle's feces for nourishment, after which time the gods took pity on Prometheus and sent Heracles to release him. When Heracles arrived, he had to surmount a titanic mound of excrement, an excruciating task that took another three thousand years due to the stench. At long last, Prometheus tries to refuse Heracles' assistance, accustomed as he is to living in and feeding off of the refuse. In Rolf Abderhalden's estimation, Prometheus is in a paradoxical situation, one which rejects any univocal interpretation, it is "una especie de tensión paradójica, una contradicción que hace que su fábula no puede concluir de manera definitiva y unívoca" (95). As such, Müller's telling of the Prometheus myth stands as a provocative parallel to the lives of El Cartucho's residents, who were residing in a barrio which was both extraordinarily dangerous and also a refuge.

Mapa Teatro allowed the residents to respond to Müller's text and to their experience in the barrio in whichever way they saw fit. The Prometheus myth acted as a sounding board, conduit, and catalyst for the personal histories of El Cartucho's residents. According to Abderhalden, the myth functioned as a ready-made, "un objeto encontrado que es sacado de su contexto para ser interpretado y re-significado por una multiplicidad de lecturas, de miradas, y de gestos" (96). The workshop culminated in the two live performances of Proyecto Prometeo, which were conceived and developed as a way of giving a voice to the displaced residents of El Cartucho and shedding light on their histories - histories which did not align with the stigmatized mythology the barrio. These performances re-situated a marginalized community at the center of Bogotá, and reconstructed the lives and memories of the residents of the neighborhood, even as their homes and businesses were being deconstructed by the state in the name of urban renewal. For the first performance, some of the buildings of El Cartucho still stood, while the 
second performance was staged after demolition was finished and the barrio was a completed ruin. The residents' demolished homes were reimagined in each performance as the former locations of the streets and buildings of El Cartucho were re-mapped with thousands of candles set out on the ruins. Each of the residents brought to the performance pieces of furniture from one of their favorite rooms in their demolished homes. These living spaces were then recreated and resituated in the performance - the residents' own furniture, their chairs, cabinets, tables, beds, and even a toilet replaced in the same space they had once occupied, resting on the stones which had once given them shelter, engaging and communicating with their own ghosts, intentionally blurring the art/life and subject/object binaries. These partially reconstructed living spaces became the sites of performance for the former residents, each of whom responded to or presented their own interpretation of a fragment of Müller's myth. Some of the residents chose to speak the text while performing their former daily tasks in the kitchen or living room. Others commented on the story or interpreted their own lives through Prometheus's struggle and Heracles's attempts to rescue him. One young woman chose to perform her piece with a bed, stepping up on it and hopping off, surmounting her own imagined obstacle as she described the fear of beds she had harbored when she first arrived in El Cartucho as a young girl - until then she had never slept in one before. In each case, the rituals of everyday life were emphasized, underscoring the value of the routines and repertoires of behavior lost.

The lives revealed in the performances were not the extraordinary, but rather the wonderfully ordinary - the unique daily routines, desires, and fears of a cross-section of Colombian individuals. Notably missing from the performance were the mythical characters of El Cartucho; there were no drug dealers, addicts, or prostitutes. The performances did not deny the dangers of the barrio, but rather revealed representatives of a silenced community, whose quotidian rituals cry out against the stigmatized image of El Cartucho as Bogotá's centro de temor. Prometeo gave a voice to those who had found refuge and relief in a perilous place. The stigma of danger cloaking El Cartucho had obscured the travails of those who had nowhere else to go. In opposition to this stigmatization, Prometeo rebuilt the histories of ways of doing, of modos de hacer, asserting the cultural citizenship of a marginalized community, a community literally removed from the center of the city, thereby repositioning citizenship within the urban landscape. Prometeo brought artistic scrutiny to the marginalized status of citizens dis- 
placed by violence, acknowledging their history as Bogotá's history—as Bogotano history.

Even though the two performances of Prometeo included actual residents, their voices and stories were mediated by the workshop process shaped by the artists at Mapa Teatro. Moreover, many of the interviews Mapa Teatro conducted with the residents were video recorded and projected during the performance. The curation of these video projections - the selection and editing process - further mediates the story of the residents' lives. Within the performances of Proyecto Prometeo, the projections humanize the desechables, the disposable people whose homes and livelihoods had been erased, but while the humanization of a marginalized community might be applauded, mediated humanization risks a homogenizing effect; to an extent, the work of Mapa Teatro has cleaned the neighborhood of both the mounds of refuse for which El Cartucho had come to be known and the criminal element. Not one of the residents included in the workshop or performances was an acknowledged criminal; there were no dealers, addicts, or prostitutes among the participants. While several of them recount in the performances and interviews some of the hardships endured by living in the crime-ridden neighborhood, the criminals themselves have no presence in the performance. There is an aesthetic distance palpable in the performance, a distance generated by fragmented memory, mediation, and physical location, a distance and fragmentation that has continued to increase as time has passed and as the projects of Mapa Teatro have moved away from the original site of El Cartucho to their headquarters on Carrera Séptima, to MAMBO, and eventually around the globe.

Re-corridos, which ran concurrently with the Prometeo: Acto Segundo, was the first of two multi-media installations created by Mapa Teatro out of the archive they generated in El Cartucho. While Prometeo re-constructed histories on the rubble of El Cartucho, Re-corridos exposed those histories to new audiences outside of the original boundaries of the barrio. Installed in Mapa Teatro's headquarters on the very busy pedestrian-only stretch of Seventh Avenue (Carrera Séptima) and open to the public, Re-corridos invited a broad swathe of Bogotás population to experience the histories of El Cartucho. The sights, sounds, and smells of the barrio present in the installation continued the project of de-centering the myth of El Cartucho, giving voice to the histories of the residents and their daily rituals. While these histories were evoked in Re-corridos, the installation took place far outside 
of the demolished barrio, a gap that was bridged in part by the next installation produced by Mapa Teatro.

A year after Re-corridos, Mapa Teatro developed a second multi-media installation, La limpieza de los establos de Augías (2004). Construction of the Parque Tercer Milenio had begun and a barrier had been raised so that passersby were unable to view the progress. Despite a lack of support from the city, Mapa Teatro installed video cameras around and above the fence to broadcast the ongoing work in real time to MAMBO, while a series of video monitors were installed on the fence itself that played footage of the demolition of El Cartucho. The two halves of the installation invited those pedestrians around the former barrio to come to the museum to see the construction they could only listen to from their vantage point. Likewise, those visitors to the museum were compelled to travel to the site of El Cartucho/ Parque Tercer Milenio. In this way La limpieza de los establos de Augías inscribed a new pathway for the citizens of Bogotá, and many of the visitors to the museum traveled to El Cartucho for the first time, while some of the residents around the ruined neighborhood made their first journey to the MAMBO.

Each of these performance installations juxtapose fragments of the physical neighborhood El Cartucho with the neighborhood as it is/was lived and imagined. The audience-as-citizens encounter with El Cartucho is actual, virtual, and mediated all at once. Moreover, each of the install-actions required the citizens-as-audience to experience the imagined space through quotidian behavior. In Proyecto Prometeo they walked on the rubble of the streets, experiencing the performed histories of the residents among imagined, no-longer-present buildings, while in Re-corridos they passed through the actual façade of one of the buildings in order to encounter documentary fragments of the resident's lives. In La limpieza de los establos de Augías spectators traveled between two physical locations to experience the past insitu and the present from a mediated distance, while in Testigo a las ruinas, the life and daily routine of one resident is foregrounded and privileged over the documentary history of the space.

Each of these installations was progressively more distant and more mediated from the original location of the barrio. Re-corridos and Las limpias de los establos de Augías involved both fragmented physical links to El Cartucho as well as installations in locations elsewhere in Bogotá, and neither directly involved the former residents of the neighborhood. The last piece in the series, Testigo a las ruinas, summarizes the work Mapa Teatro 
did with the El Cartucho residents. This performance travels internationally, further distancing the work from its original location, and only occasionally incorporates one of the original residents, the last original resident Juana Ramírez. Thus, the series followed a trajectory of increasing mediation, fragmentation, and physical distance from the neighborhood it seeks to memorialize, much like memory itself.

Any attempt to understand the performances of Prometeo must take into account the social mythology of the space in which the performance took place, a mythology rooted in the patterns of social behavior. Public spaces are ghosted not only by events, but also by behavioral histories that evolve over time. Patterns of behavior repeated within a given social space not only contribute to the construction of socialized space, but also the construction of cultural citizenship and social identity. These patterns of behavior constitute a code, one of the languages of membership within a community. Thus, communities informally establish citizenship through repertoires of behavior, through codes of conduct. The demolition of El Cartucho, and with it a history of modos de hacer, constitutes a partial erasure of the cultural citizenship of this community. Not only have their houses and businesses been destroyed, and their lives physically marginalized - shoved away from the center of power - but part of the very basis of their claim to cultural citizenship within Bogotá has been revoked through the obliteration of the socially constructed spaces that enabled their repertoires of behavior.

\section{Re-imagining space}

The transformation of the historic El Cartucho into the no-lugar Parque Tercer Milenio was one of several projects initiated by Enrique Peñalosa, Bogotá's mayor from 1998 to 2000. Peñalosa's other projects included the city-wide network of busses, known as TransMilenio, as well as other parks, schools, local libraries, and urban renovation projects. Karen Till's article, "'Greening' the City? Artistic Re-Visions of Sustainability in Bogotá," criticizes the rhetoric of "urban renewal, revitalization, gentrification, and most recently sustainability," under which Peñalosa has been praised for his accomplishments. For Till, this rhetoric "assumes problematic analogies between places and commodities, between cities and entrepreneurial firms." Till undermines this rhetoric by deconstructing what she calls the "spatial imaginaries" of the politicians and urban planners involved. The spatial imaginary of late capitalist neoliberalism conceives of social space through a logic predicated on economic development and land-use values, overlook- 
ing the value of human relations, human rights, and cultural history. The urban landscape is divided up into properties that can be evaluated as either good or bad based on property value and economic potential. Till examines Mapa Teatro's work as an alternative spatial imaginary that can "remind us that places are lived, performed, and inhabited" and that these social spaces, "invite residents to explore the lingering and possible pathways of remnant landscapes, material objects, and forms of belonging." I suggest that modos de hacer are key to cultural citizenship and "forms of belonging." To demolish a social space not only displaces human lives, it demolishes human trajectories, pathways of human social interaction; it is to demolish a fragment of what it means to belong to the surrounding community. The decision to transform El Cartucho into a public park arose from an economic spatial imaginary, one that ignored the value of both the present and the past.

Like Till, Doreen Massey has also sought to complicate the ways in which space is imagined. For Massey, all too often space is flattened out, conceived of simply as a map, an abstract surface: "So easily this way of imagining space can lead us to conceive of other places, peoples, cultures simply as phenomena 'on' this surface. It is not an innocent manoeuvre [sic], for by this means they are deprived of histories" (4). Massey argues that space has been reducible to time in the history of thought; space, she argues, is understood as a slice of time or equated with representation. Understanding space, as she says, as an "open ongoing production.... makes room for a genuine multiplicity of trajectories, and thus potentially of voices" (55). It is precisely this multiplicity of trajectories and voices that Mapa Teatro's performance installations have revealed.

El Cartucho exemplifies a neighborhood whose place in the social imaginary is less dependent on the architecture of the buildings or the history of specific events that have taken place within its boundaries, than it was on stigmatized repertoires of behavior that evolved over time. Thus, understanding how the audience may have interpreted the performances of Prometeo requires knowledge of the conflict between the stigmatized mythology that El Cartucho was a dangerous barrio full of gangs and drug addicts and the space as it was lived by the majority of its residents. Prometeo recreated the living spaces of some of the residents - a bathroom, a kitchen, a living room - as if to say, these were regular people who lived their lives in the best way that they could. They were poor, many internally displaced, and this neighborhood offered shelter, a means for survival in Bogotá's social landscape. The destruction of the neighborhood was the elimination of 
lived spaces, with complex social history, whose evolution has been ongoing since the first houses were built. Prometeo did not just commemorate the loss of a space; it confronted the neoliberal spatial imaginary of the city that viewed the neighborhood as a blighted space in need of improvement.

By employing in the performances actual residents of El Cartucho, by offering the residents a way to re-live the space, Prometeo opened to the audience a window into the human condition of the space. Ileana Diéguez Caballero writes, "Atravesada por la tensión entre universos míticos, experiencias reales y estéticas, esta acción generaba una antiestructura utópica en el mismo corazón de la ciudad" (156). Her book, Escenarios liminales: Teatralidades, performances y política, examines transdisciplinary artworks as intersections open to multiple trajectories. Not only did Prometeo reveal unexpected lives, it was itself performed in an unexpected form that privileged the non-artists, allowing the residents to write and perform their own histories, albeit under the guiding hand of Mapa Teatro. This utopian antistructure counters neoliberal narratives of economic progress in its lament for the loss of real, lived homes and livelihoods. In her book on photography of the city of Bogotá, art critic Natalia Gutiérrez examines those photographers who, in her view, capture with their photography the forms and relations that shape the city (11). She suggests these works of art capture, "una ciudad creadora de lugares comunes, territorios de nadie y, paradójicamente, lugares donde se cumplen algunos de los deseos inconfesables y se conocen aspectos desconocidos de la propia personalidad" (12). Gutiérrez's notion of the ciudad-espejo - an image of the city that reflects more than the physical spaces depicted - is closely related to Foucault's heterotopias, which he develops in his essay "Different Spaces." Heterotopias are simultaneously real and imagined, specifically localizable objects or places that also conjure imagined objects or places. The mirror is Foucault's primary example of a heterotopia, an object that has an actual physical presence, but which also contains a "contested, represented, and reversed" presence (178). The face in the mirror is not actually there on the surface of the mirror, nor is it an accurate representation of the face it reflects; it is, in fact, reversed. Like Gutiérrez's mirrors and Foucault's heterotopias, Prometeo reflected back more than was on the surface: a representation that was reversed, a mythology founded on a fact that had outgrown the truth, a spatial imaginary that had proven inadequate through the no-longer quiet voices of those who had been pushed aside. 
The spatial imaginary that led to the eviction of El Cartucho's residents did not seek to provide new opportunities for those residents, although they were given a modicum of social assistance. Instead, the goal seems to have been to eliminate criminal activities by erasing the social spaces in which those criminal activities took place, all in the name of gentrification and green space for the city. This conception of the neighborhood conflated the illegal activities of a few with the peaceful activities of the poor. As the performances of Prometeo attest, El Cartucho was home to more than drug dealers and thugs. There was an expectation on the part of the authorities that once El Cartucho was demolished there would emerge from the ruins around three hundred drug-addicts who would have nowhere else to go. The houses full of addicts would no longer exist, and the addicts, the mummies as they were called, would need to be dealt with by the authorities (Mapa Teatro). There were no mummies. Not one of the fifteen residents involved in the two performances of Prometeo was a drug dealer. They were young and old, having traveled to El Cartucho from a variety of different locations throughout Colombia, and with a variety of cultural backgrounds. One of the few things they had in common was a need for a place within society, and El Cartucho had been supplying that need. However full of crime, the majority of the residents were still peaceful, no matter how hopeless the site may have at that time appeared to be.

\section{Conclusion}

Discourse on history, memory, and social identity in Latin American theatre has strongly favored the politics of performance and the body, and while social space certainly arises in these discussions, it seems to me that an integrated theory of social space and performance has yet to be articulated. What do we have to gain by reasserting (or reinserting) social space into the discourse of memory, history, and politics of Latin America? To what extent has discourse on material space - actual places - been superseded by discourse on idealized space, thereby privileging the abstract over the actual? The performances of Mapa Teatro and Antanas Mockus illuminate a deeper understanding of community formation - one that sees community as a heterogeneous population living within a shared and relational spacea notion of community that does not solve, avoid, or eclipse the problems posed by colonialism, neoliberalism, or globalization. Moreover, much of our discourse itself is constructed in spatialized language; we frequently read and discuss globalization, colonization, topographies, maps, frames, 
intersections, liminality, and marginalization. This rhetoric creates mental, abstract topographies, rather than describing or attempting to understand the actual topography, the physical landscape itself, and especially the repertoires of behavior, the modos de hacer, the everyday habits of those who live, work, play, visit, or just pass through any given social space, and the ways in which these trajectories shape and are shaped by that space. Each and every one of these quotidian performances contributes to the construction of the social space, the ways in which a place is encountered and negotiated, just as the place itself shapes and organizes those behaviors. That is to say that the modos de hacer visible on any one occasion are organized and shaped by the history of behaviors that have gone before in the same geographic place. Artistic and political performances and installations like those of Mapa Teatro and Mockus's Cultura ciudadana suggest that daily patterns of behavior can be intentionally interrupted, or consciously maneuvered. When these intentional interruptions are repeated on a large enough scale - depending on the community in question - they open the opportunity for re-alignment of the very repertoires in question through the body's own instinctive or latent processes. Cultural citizenship within a community may therefore be intentionally altered, though perhaps not explicitly shaped by performed interruptions, given wide enough attention and/or repetition.

Through Mapa Teatro's performances and installations, the lives of the residents of El Cartucho counter-acted the stigmatized mythology of the barrio, re-centering a marginalized community and reasserting their cultural citizenship. Vicky Unruh has observed that contemporary Latin American artists, "link the urban-ruins trope to constructive, nonutopian imaginings of a less ruinous future and to creative engagements with the city landscape, however devastated, in search of something of value" (136). In the case of Mapa Teatro's work in El Cartucho, I suggest that the value the artists are seeking is an acknowledgement that urban spaces, and especially neighborhoods, are always linked to human lives and human behavior. Unruh also notes that ruins are associated with what she calls, "the underbelly or dark side of Western modernity's rationalist narratives of unfettered progress" (136). Indeed, Peñalosa's work, including the demolition of El Cartucho and its transformation into a verdant park, has been widely hailed by economists and sociologists as a significant accomplishment in the transformation of the city into a safer, more modern global city. The transformation of El Cartucho can be read, however, not only as a transformation from a blighted neighborhood to a clean (?) and safer (??) park, but also as a transformation 
from a valuable cultural space, carrying within its walls and streets a history of the city and the people's lives who had intersected with the topography, to a non-place, an ordinary replication of twenty-first century parks that might just have easily existed near my house in Columbus, Ohio, as it does in Bogotá. Walking through the Parque Tercer Milenio on an ordinary afternoon, one is struck by the disuse of the park. Playgrounds are eerily quiet, fields are barren except for bits of refuse, and a plethora of permanent performance stages stand agape, silently singing of empty concrete slabs, bringing into question any notion of progress that substitutes one kind of ruin for another.

\section{Ohio State University}

\section{Notes}

1 The United Nations High Commissioner for Refugees website lists 6,044,151 displaced persons in Colombia for 2015. www.unhcr.org. Retrieved 12 Dec. 12, 2015.

2 Antanas Mockus was mayor of Bogotá from January 1, 1995 to April 10, 1998 and again from January 1, 2001 to December 31, 2003. He resigned the office in 1998 in order to campaign, unsuccessfully, for the presidency.

3 The field of cultural citizenship studies blossomed from T. H. Marshall's 1964 essay, "Citizenship and Social Class," but has largely focused on the cultural citizenship of nation-states, thereby favoring national culture over the cultural heritage of regional communities, as well as those of indigenous and minority groups.

4 Müller's prose version of the Prometheus story is a short fragment of his longer play, Cement (1975).

\section{Works Cited}

Abderhalden Cortés, Rolf. "El artista como testigo: testimonio de un artista." Arte y etnografia: De artistas, textos, contextos, mapeos y paseantes. Ed. Pedro Pablo Gómez. Bogotá: Universidad Distrital Francisco José de Caldas, 2007. 91-102. Print.

Augé, Marc. Non-Places: An Introduction to Supermodernity. $2^{\text {nd }}$ ed. Trans. John Howe. London: Verso, 2008. Print.

Barthes, Roland. Mythologies. Ed. and Trans. Annette Lavers. New York: Hill and Wang, 1972. Print.

Diéguez Caballero, Ileana. Escenarios liminales: teatralidades, performances y política. Buenos Aires: Atuel, 2007. Print. 
Foucault, Michel. "Different Spaces." Aesthetics, Method, and Epistemology. Ed. James D. Faubion. Trans. Robert Hurley. New York: New Press, 1998. Print. 175-86. . Power/Knowledge: Selected Interviews and Other Writings 1972-1977. Ed. Colin Gordon. Trans. Colin Gordon, Leo Marshall, John Mepham, and Kate Soper. New York: Pantheon, 1980. Print.

Gutiérrez, Natalia. Ciudad-espejo. Bogotá: Universidad Nacional de Colombia, 2009. Print.

Llorente, María Victoria, and Ángela Rivas. "La caída del crimen en Bogotá: una década de políticas de seguridad ciudadana." Washington: Departamento de Finanzas, Sector Privado e Infraestructura para América Latina del Banco Mundial, 2005. Centro Virtual de Aprendizaje. Web. 13 Mar. 2014.

Mapa Teatro. "Truth is Concrete, 22/09, 19:00; Mapa Teatro: Witness to the Ruins." Online Video Clip. Posted by steirischerherbst. YouTube. YouTube, 2 Nov. 2012. Web. 13 Mar. 2014.

Marshall, T. H. "Citizenship and Social Class." The Citizenship Debates: A Reader. Ed. Gershon Shafir. Minneapolis: U of Minnesota P, 1998. 93-111. Print.

Massey, Doreen. For Space. London: SAGE, 2005. Print.

Mockus, Antanas. Cultura ciudadana: Programa contra la violencia en Bogotá, Colombia, 1995-1997. Washington, D.C: Banco Interamericano de Desarrollo, 2002. Web. 13 Mar. 2014.

Müller, Heiner. Cement. Trans. Helen Fehervary, Sue-Ellen Case, Marc D. Silberman. Milwaukee: New German Critique, 1979. Print.

Pakulski, Jan. "Cultural Citizenship." Citizenship Studies 1.1 (1997): 73-86. Taylor and Francis Online. Web. 14 Sept. 2014.

Rama, Angel. La ciudad letrada. Hanover: Ediciones del Norte, 1984. Print.

Till, Karen E. "'Greening' the City? Artistic Re-Visions of Sustainability in Bogotá." E-misférica 7.1 (2010). Hemispheric Institute. Web. 17 Apr. 2015.

Truth is Concrete. Steirischer Herbst .Web. 13 Mar. 2014. www.truthisconcrete.org. United Nations High Commission for Refugees. Web. www.unhcr.org. 12 Dec. 2015.

Unruh, Vicky. “It's a Sin to Bring Down an Art Deco': Sabina Berman's Theater among the Ruins.” PMLA (2007): 135-50. JSTOR. Web. 11 Apr. 2015. 